\title{
Potentiating effect of inhaled acetaldehyde on bronchial responsiveness to methacholine in asthmatic subjects
}

\begin{abstract}
Shigeharu Myou, Masaki Fujimura, Kohichi Nishi, Masako Matsuda, Takio Ohka, Tamotsu Matsuda
\end{abstract}

\begin{abstract}
Background - It has recently been reported that acetaldehyde induces bronchoconstriction indirectly via histamine release. However, no study has been performed to assess whether acetaldehyde worsens bronchial responsiveness in asthmatic subjects so this hypothesis was tested.

Methods-Methacholine provocation was performed on three occasions: (1) after pretreatment with oral placebo and inhaled saline (P-S day), (2) after placebo and inhaled acetaldehyde (P-A day), and (3) after a potent histamine $H_{1}$ receptor antagonist terfenadine and acetaldehyde ( $T$-A day) in a double blind, randomised, crossover fashion. Nine asthmatic subjects inhaled $0.8 \mathrm{mg} / \mathrm{ml}$ acetaldehyde or saline for four minutes. After each inhalation a methacholine provocation test was performed.
\end{abstract}

Results - Methacholine concentrations producing a $20 \%$ fall in $\mathrm{FEV}_{1}\left(\mathrm{PC}_{20}-\mathrm{MCh}\right)$ on the P-A day $(0.48 \mathrm{mg} / \mathrm{ml}, 95 \%$ CI 0.21 to 1.08$)$ and T-A day $(0.41 \mathrm{mg} / \mathrm{ml}, 95 \% \mathrm{CI}$ 0.22 to 0.77$)$ were lower than those on the P-S day $(0.85 \mathrm{mg} / \mathrm{ml}, 95 \%$ CI 0.47 to 1.54$)$. There was no change in the $\mathbf{P C}_{20}-\mathbf{M C h}$ between the P-A and T-A days. A correlation was observed between the logarithmic values of $\mathbf{P C}_{20}-\mathbf{M C h} \quad(\log$ $P_{20}-M C h$ ) on the P-S day and the potentiating effect of acetaldehyde on the methacholine responsiveness $[(\log$ $\mathbf{P C}_{20}-\mathbf{M C h}$ on P-A day $)-\left(\log \mathbf{P C}_{20}-\mathbf{M C h}\right.$ on P-S day)] $($ rho $=0.82)$.

Conclusions - Acetaldehyde induces bronchial hyperresponsiveness in patients with asthma by mechanisms other than histamine release.

(Thorax 1994;49:644-648)

Exacerbation of asthmatic symptoms by alcoholic drinks or ethanol induced bronchoconstriction has been observed among $55 \%$ of Japanese asthmatic patients. ${ }^{1}$ Ethanol is not considered a bronchoconstrictor in Japanese patients, ${ }^{12}$ while alcohol in itself is a bronchoconstrictor and a bronchodilator when given either orally or by inhalation in the white population..$^{3-5}$

Ethanol is oxidised to acetaldehyde which, in turn, is oxidised to acetate mainly by aldehyde dehydrogenase (ALDH). This consists of two main isozymes with low and high Michae-
lis-Menten constant (the substrate concentration at which an enzyme catalysed reaction proceeds at one half its maximum velocity) for aldehyde. ${ }^{6-8}$ About $50 \%$ of Japanese people lack the enzyme with a low Michaelis-Menten constant (ALDH 2) and show an elevation of serum acetaldehyde concentration due to their inability to metabolise acetaldehyde quickly and effectively. ${ }^{9-11}$ It has been reported that ALDH 2 activity is a major determining factor of asthmatic exacerbations after drinking pure ethanol or alcoholic beverages in Japanese asthmatic subjects, and that changes in specific airway conductance are closely related to blood acetaldehyde levels. ${ }^{2}$ We recently showed that inhaled acetaldehyde causes bronchoconstriction indirectly via histamine release in asthmatics, ${ }^{12}$ and that the release of histamine made a major contribution to bronchoconstriction provoked after oral administration of alcohol (unpublished data). These findings suggest that acetaldehyde plays an important part in ethanol induced bronchoconstriction in Japanese subjects.

On the other hand, the severity of bronchial hyperresponsiveness correlates closely with the severity of symptoms, ${ }^{1314}$ with the amount of treatment required to control symptoms, ${ }^{15}$ and with the diurnal variation of airway function. ${ }^{16}$ No study has been performed, however, to investigate the effect of acetaldehyde on bronchial responsiveness in asthmatic subjects.

We wished to determine (1) whether bronchial responsiveness to inhaled methacholine was altered when asthmatic subjects inhaled a subthreshold concentration of aerosolised acetaldehyde which did not cause bronchoconstriction per se, and (2) whether any increase in bronchial hyperresponsiveness after acetaldehyde was mediated by histamine release.

\section{Methods}

SUBJECTS

Nine asthmatic patients with a mean (SE) age of $46.1(6.7)$ years participated in the study (table 1). None had ever smoked and all had avoided respiratory tract infection for at least eight weeks before the study. Each patient satisfied the American Thoracic Society definition of asthma. ${ }^{17}$

The study was carried out when their symptoms were mild and stable while they were taking an aerosol $\beta_{2}$ agonist, oral theophylline, or both. They had not received treatment with steroids for at least eight weeks. Informed 
Table 1 Subject characteristics

\begin{tabular}{|c|c|c|c|c|c|c|c|c|}
\hline Subject no. & $\begin{array}{l}\text { Age } \\
\text { (years) }\end{array}$ & Sex & $\begin{array}{l}\operatorname{Ig} E \\
(I U / \mathrm{ml})\end{array}$ & $\begin{array}{l}F V C \\
(\% \text { predicted) }\end{array}$ & $\begin{array}{l}F E V, \\
(\% \text { predicted })\end{array}$ & $\begin{array}{l}F E V_{l} / F V C \\
(\%)\end{array}$ & $\begin{array}{l}P C_{20}-A c C H O \\
(m g / m l)\end{array}$ & Treatment \\
\hline $1^{*}$ & 66 & M & 870 & $105 \cdot 8$ & $89 \cdot 6$ & $66 \cdot 9$ & $30 \cdot 5$ & $\mathrm{Sa}$ \\
\hline $2^{*}$ & 27 & $\mathbf{M}$ & 100 & $117 \cdot 7$ & $79 \cdot 6$ & $62 \cdot 3$ & $12 \cdot 8$ & $\mathrm{Sa}, \mathrm{Th}$ \\
\hline $3^{*}$ & 29 & $\mathbf{M}$ & 2300 & 105.9 & $78 \cdot 7$ & $68 \cdot 2$ & $30 \cdot 8$ & $\mathrm{Sa}, \mathrm{Th}$ \\
\hline $4^{*}$ & 22 & $F$ & 590 & $86 \cdot 0$ & $77 \cdot 7$ & $83 \cdot 3$ & $20 \cdot 9$ & \\
\hline $5^{*}$ & 29 & $\mathbf{M}$ & 28 & $110 \cdot 0$ & $78 \cdot 3$ & $66 \cdot 0$ & $21 \cdot 2$ & $\mathrm{Sa}, \mathrm{Th}$ \\
\hline 6 & 51 & $\mathbf{M}$ & 22 & $70 \cdot 0$ & $85 \cdot 1$ & $66 \cdot 6$ & $21 \cdot 6$ & $\mathrm{Sa}, \mathrm{Th}$ \\
\hline 7 & 73 & $\mathbf{M}$ & 1800 & $83 \cdot 7$ & $83 \cdot 3$ & $67 \cdot 2$ & $18 \cdot 6$ & $\mathrm{Sa}, \mathrm{Th}$ \\
\hline 8 & 51 & $\mathbf{F}$ & 39 & $104 \cdot 5$ & 73.9 & $60 \cdot 9$ & $24 \cdot 7$ & $\mathrm{Th}$ \\
\hline 9 & 68 & $\mathrm{~F}$ & 10 & $87 \cdot 0$ & $100 \cdot 0$ & $80 \cdot 0$ & $38 \cdot 4$ & Th \\
\hline Mean & $46 \cdot 2$ & & 639.9 & $96 \cdot 7$ & 82.9 & $69 \cdot 0$ & $23 \cdot 3$ & \\
\hline SE & $6 \cdot 6$ & & 287.8 & & & & & \\
\hline $95 \%$ CI lower & & & & $\begin{array}{r}84 \cdot 8 \\
108 \cdot 7\end{array}$ & $\begin{array}{l}76 \cdot 8 \\
89 \cdot 0\end{array}$ & $\begin{array}{l}63 \cdot 2 \\
74 \cdot 9\end{array}$ & $\begin{array}{l}18 \cdot 2 \\
29 \cdot 9\end{array}$ & \\
\hline
\end{tabular}

$\mathrm{Sa}=$ salbutamol via metered dose inhaler; $\mathrm{Th}=$ oral theophylline; $\mathrm{FVC}=$ forced vital capacity; $\mathrm{FEV}_{1}=$ forced expiratory volume in one second; $\mathrm{PC} \mathrm{C}_{20}=\mathrm{AcCHO}=\mathrm{acet}-$ aldehyde concentration producing a $20 \%$ fall in $\mathrm{FEV}_{1}$.

consent was obtained from all subjects. This study was approved by the ethics committee of our hospital.

\section{STUDY PROTOCOL}

Non-specific bronchial responsiveness was measured on three occasions, each two weeks apart: (1) after pretreatment with oral placebo and inhaled saline (P-S day), (2) after placebo and inhaled acetaldehyde (P-A day), and (3) after a potent histamine $H_{1}$ receptor antagonist terfenadine and acetaldehyde ( $\mathrm{T}-\mathrm{A}$ day) in a double blind, randomised, crossover fashion. Terfenadine was given orally in a dose of $60 \mathrm{mg}$ twice a day for three days and at 08.00 and 13.00 hours on the fourth (test) day. Placebo was administered by the same procedure as terfenadine. All medication, except for pretreatment with terfenadine and placebo, was stopped at 13.00 hours on the day before the test day to allow a washout time of at least 24 hours. The bronchial responsiveness to inhaled acetaldehyde was then measured at 15.00 hours on the test day.

\section{AEROSOLISED ADMINISTRATION OF ACETALDEHYDE OR SALINE}

An acetaldehyde concentration producing a $20 \%$ fall in $\mathrm{FEV}_{1}\left(\mathrm{PC}_{20}-\mathrm{AcCHO}\right)$ was determined as previously described ${ }^{12}$ (table 1$)$. Acetaldehyde was dissolved in physiological saline to make a solution of $0.8 \mathrm{mg} / \mathrm{ml}$, the subthreshold concentration having no direct bronchoconstrictor effect itself in a preliminary study. Acetaldehyde and saline were inhaled from a DeVilbiss 646 nebuliser (DeVilbiss, Somerset, Pennsylvania, USA) opeated by compressed air at $5 \mathrm{l} / \mathrm{min}$. The nebuliser output was $0.14 \mathrm{ml} / \mathrm{min}$. Each solution was inhaled for four minutes by tidal breathing with the nebuliser while wearing a noseclip, and this was followed immediately by measurements of $\mathrm{FEV}_{1}$.

MEASUREMENT OF BRONCHIAL RESPONSIVENESS Non-specific bronchial responsiveness was evaluated by methacholine challenge. Methacholine chloride was dissolved in physiological saline solution to make concentrations of 0.04 , $0.08,0.16,0.31,0.63,1.25,2.5,5,10$, and
$20 \mathrm{mg} / \mathrm{ml}$. Saline and methacholine were inhaled from a DeVilbiss 646 nebuliser operated by compressed air at $5 \mathrm{l} / \mathrm{min}$. Saline was inhaled first for two minutes and FEV, measured. If the change in $\mathrm{FEV}_{1}$ from the baseline value was $\leqslant 10 \%$ inhalation of methacholine was started, and if the saline solution caused a change in $\mathrm{FEV}_{1}$ of $>10 \%$ the test was stopped or postponed. Methacholine was inhaled for two minutes by tidal breathing and followed immediately by measurements of $\mathrm{FEV}_{1}$. Increasing concentrations of methacholine were inhaled until a fall of $20 \%$ or more in FEV 1 occurred. These values were plotted on semilogarithmic graph paper and a methacholine concentration producing a $20 \%$ fall in $\mathrm{FEV}_{1}\left(\mathrm{PC}_{20}-\mathrm{MCh}\right)$ was determined from the post saline $\mathrm{FEV}_{1}$ value before the first inhalation of methacholine. $\mathrm{FEV}_{1}$ was measured three times and the best value of three attempts was recorded each time.

\section{DATA ANALYSIS}

$\mathrm{FEV}_{1}$ data were expressed as mean and $95 \%$ confidence intervals ( $95 \% \mathrm{CI}$ ). Analysis of variance (ANOVA) was used for differences in baseline $\mathrm{FEV}_{1}$ between the three test days. $\mathrm{FEV}_{1}$ values and percentage changes in $\mathrm{FEV}_{1}$ from the preinhalation value after inhalation of either acetaldehyde or saline were also analysed by ANOVA. $\mathrm{PC}_{20}-\mathrm{MCh}$ values were logarithmically transformed for analysis and reported as the geometric mean $(95 \% \mathrm{CI})$. ANOVA followed by Fisher's protected least significant difference was used to analyse changes in $\mathrm{PC}_{20}-\mathrm{MCh}$ induced by treatment with acetaldehyde or saline. The degree of augmentation of methacholine responsiveness by acetaldehyde $\left(\triangle \mathrm{PC}_{20}-\mathrm{MCh}\right)$ was calculated as the difference between the logarithmic values of $\mathrm{PC}_{20}-\mathrm{MCh}$ on the $\mathrm{P}-\mathrm{A}$ and $\mathrm{P}-\mathrm{S}$ days, and the logarithmic value of $\mathrm{PC}_{20}-\mathrm{MCh}$ on the $\mathrm{P}-\mathrm{S}$ day was used as the baseline bronchial responsiveness. Correlations were obtained using Spearman's non-parametric rank correlation. A value of $p<0.05$ was accepted for statistical significance.

\section{Results}

Baseline $\mathrm{FEV}_{1}$ and percentage changes in $\mathrm{FEV}_{1}$ from the baseline value induced by inha- 


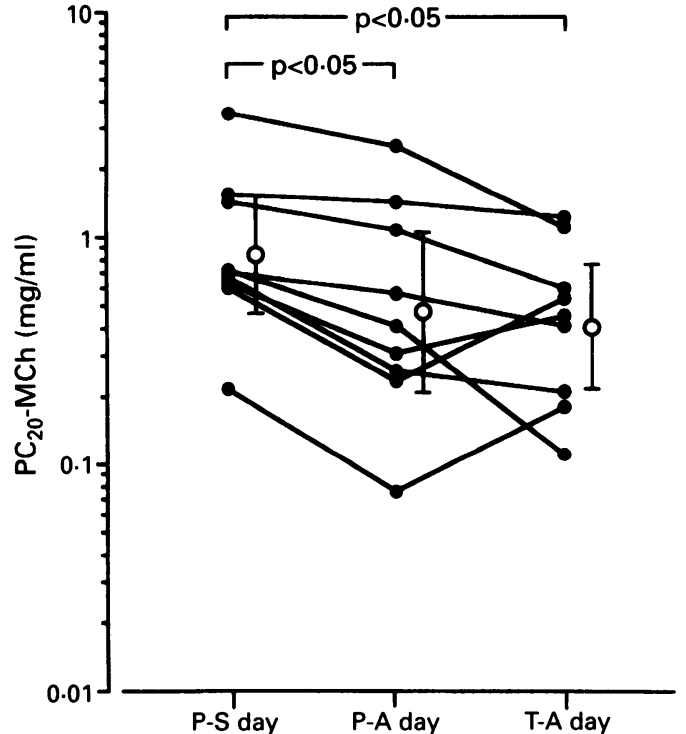

Figure 1 Effect of inhaled acetaldehyde on $P C_{20}-M C h$ (the provocative concentration of methacholine producing a $20 \%$ fall in $F E V_{1}$ ) and effect of four days

pretreatment with terfenadine on the acetaldehyde induced bronchial hyperresponsiveness to methacholine in nine asthmatic subjects (closed circles). Open circles: geometric mean $(95 \% \mathrm{CI})$ of $P C_{20}-M C h ; P-S$ day: after pretreatment with oral placebo and inhaled saline, $P$ - $A$ day: placebo and inhaled acetaldehyde; $T$ - $A$ day: terfenadine and acetaldehyde.

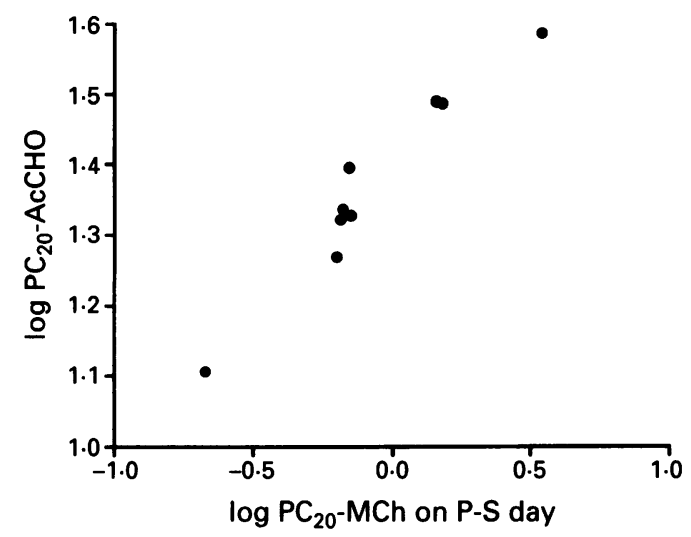

Figure 2 Relation between the logarithmic values of $P_{20}-M C h$ on $P-S$ day and $P C_{20}-A c C H O$ (the provocative concentration of methacholine and acetaldehyde, respectively, producing a $20 \%$ fall in $\left.F E V_{1}\right)$ in asthmatic subjects; rho $=0.93, p<0.01$. lation of either saline or acetaldehyde are shown in table 2 . Mean (95\% CI) $\mathrm{FEV}_{1}$ values after inhalation of saline or acetaldehyde were 2.34 ( 1.83 to 2.84$) 1$ after saline on P-S day, 2.33 ( 1.84 to 2.82$) 1$ after acetaldehyde on P-A day, and 2.38 ( 1.89 to 2.87$) 1$ after acetaldehyde on T-A day. There were no significant differences in the $\mathrm{FEV}_{1}$ at baseline or after inhalations between any pair of three test days. There were no significant changes in $\mathrm{FEV}_{1}$ after inhalation of each solution.

Acetaldehyde inhalation significantly increased bronchial responsiveness to methacholine (fig 1). The geometric mean $(95 \% \mathrm{CI})$ $\mathrm{PC}_{20}-\mathrm{MCh}$ significantly decreased $(\mathrm{p}<0.05)$ from $0.85(0.47$ to 1.54$) \mathrm{mg} / \mathrm{ml}$ on P-S day to $0.48(0.21$ to 1.08$) \mathrm{mg} / \mathrm{ml}$ on P-A day (a change of $0.84(0.42$ to 1.25$)$ doubling doses), and to $0.41(0.22$ to 0.77$) \mathrm{mg} / \mathrm{ml}(1.05(0.38$ to 1.71$)$ doubling doses) on T-A day. The $\mathrm{PC}_{20}-\mathrm{MCh}$ values on $\mathrm{T}-\mathrm{A}$ and $\mathrm{P}-\mathrm{A}$ days were identical. The changes in bronchial responsiveness were similar in the four patients who had never experienced alcohol-induced asthma and in the five who had.

Logarithmic values of $\mathrm{PC}_{20}-\mathrm{AcCHO}$ related to logarithmic values of $\mathrm{PC}_{20}-\mathrm{MCh}$ on $\mathrm{P}-\mathrm{S}$ day (rho $=0.93, \mathrm{p}<0.01$ ) (fig 2) and a significant correlation was observed between logarithmic values of $\mathrm{PC}_{20}-\mathrm{MCh}$ on $\mathrm{P}-\mathrm{S}$ day and the potentiating effect of acetaldehyde on methacholine responsiveness $\left(\Delta \mathrm{PC}_{20}-\mathrm{MCh}\right)(\mathrm{rho}=\mathbf{0} \cdot 82$, $\mathrm{p}<0.05$ ) (fig 3).

\section{Discussion}

The results of this study show that the subthreshold concentration of acetaldehyde caused an increase in non-specific bronchial hyperresponsiveness in asthma, and that this was related to the baseline bronchial hyperresponsiveness. Furthermore, terfenadine had no inhibitory effect on the acetaldehyde induced bronchial hyperresponsiveness.

It has been reported that acetaldehyde increases the blood and urine levels of catecholamines, ${ }^{18-20}$ and that adrenaline causes bronchodilatation. ${ }^{21} 22$ In this study we chose aerosol administration of acetaldehyde in order to examine the direct effect of acetaldehyde on airways, excluding the sympathomimetic action and the effect of ALDH 2.

Table 2 Baseline values of $F E V$, in litres and percentage change after inhalation

\begin{tabular}{|c|c|c|c|c|c|c|}
\hline \multirow[b]{2}{*}{ Subject no. } & \multicolumn{2}{|c|}{$\begin{array}{l}\text { Oral placebo }+ \\
\text { inhaled saline (P-S) }\end{array}$} & \multicolumn{2}{|c|}{$\begin{array}{l}\text { Oral placebo }+ \\
\text { inhaled acetaldehyde }(P-A)\end{array}$} & \multicolumn{2}{|c|}{$\begin{array}{l}\text { Oral terfenadine }+ \\
\text { inhaled acetaldehyde }(T-A)\end{array}$} \\
\hline & Baseline & $\%$ change & Baseline & $\%$ change & Baseline & $\%$ change \\
\hline $\begin{array}{l}1 \\
2 \\
3 \\
4 \\
5 \\
6 \\
7 \\
8 \\
9 \\
\text { Mean } \\
95 \% \text { CI lower } \\
95 \% \text { CI upper }\end{array}$ & $\begin{array}{l}2.45 \\
3.21 \\
2.94 \\
2.49 \\
3.01 \\
1.90 \\
1.74 \\
1.65 \\
1.52 \\
2.32 \\
1.83 \\
2.82\end{array}$ & $\begin{array}{r}5.3 \\
-3.4 \\
1.0 \\
-2.0 \\
4.7 \\
-1.6 \\
1.1 \\
1.2 \\
-2.6 \\
0.4 \\
-2.0 \\
2.8\end{array}$ & $\begin{array}{l}2 \cdot 48 \\
3 \cdot 18 \\
3 \cdot 16 \\
2 \cdot 49 \\
2 \cdot 76 \\
2.06 \\
1 \cdot 71 \\
1 \cdot 71 \\
1.44 \\
2 \cdot 33 \\
1.84 \\
2 \cdot 82\end{array}$ & $\begin{array}{r}-1.6 \\
-1.9 \\
3.5 \\
-2.4 \\
0.0 \\
-3.4 \\
1.2 \\
5.8 \\
0.7 \\
0.2 \\
-2.1 \\
2.5\end{array}$ & $\begin{array}{l}2.50 \\
3.17 \\
3.03 \\
2.62 \\
2.86 \\
1.97 \\
1.76 \\
1.70 \\
1.55 \\
2.35 \\
1.87 \\
2.83\end{array}$ & $\begin{array}{r}0.0 \\
4.7 \\
-2.3 \\
1.1 \\
3.1 \\
-1.5 \\
5.1 \\
4.7 \\
-5.2 \\
1.1 \\
-1.7 \\
3.9\end{array}$ \\
\hline
\end{tabular}




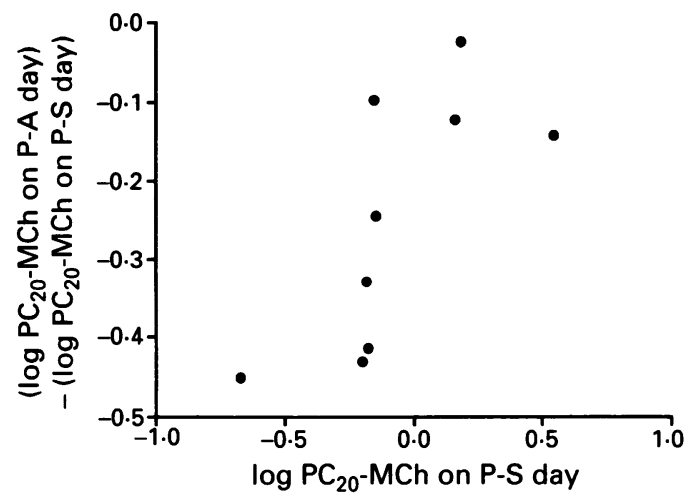

Figure 3 Relation between logarithmic values of $P C_{20}-M C h$ (the provocative concentration of methacholine producing a $20 \%$ fall in $F E V_{1}$ ) on $P-S$ day and potentiating effect of acetaldehyde on methacholine responsiveness calculated by the difference in logarithmic values of $P C_{20}-M C h$ on $P-A$ and $P-S$ days. $P-S$ day: after pretreatment with oral placebo and inhaled saline; $P-A$ day: after pretreatment with oral placebo and inhaled acetaldehyde; rho $=0.82, p<0.05$

The morning after drinking aloholic beverages exacerbation of asthmatic symptoms is observed in some Japanese asthmatic patients. The severity of bronchial hyperresponsiveness correlates closely with the severity of symptoms. ${ }^{1314}$ We therefore investigated whether acetaldehyde has a potentiating effect on methacholine responsiveness. Our data (fig 1) show that a subthreshold concentration of acetaldehyde causes bronchial hyperresponsiveness to methacholine. It suggests the need for more research to examine whether a dietary factor influences bronchial reactivity in asthmatic subjects, both with and without a history of alcohol induced bronchoconstriction, in order to control symptoms.

It has been reported that acetaldehyde causes dose dependent histamine release from leucocytes in Japanese asthmatics in vitro. ${ }^{1} \mathrm{We}$ have recently shown that acetaldehyde causes bronchoconstriction indirectly via histamine release in asthmatic subjects. ${ }^{12}$ Histamine does not generally influence reactivity to methacholine. Indeed, histamine has been shown to have no effect on radioligand binding to muscarinic receptors, ${ }^{23}$ and terfenadine failed to protect the airways against the constrictor effect of inhaled methacholine.$^{24}{ }^{25}$ Histamine, however, is a potent inducer of prostaglandin synthesis. ${ }^{26-30}$ As it could not be excluded that secondary products of acetaldehyde induced endogenous histamine cause bronchial hyperresponsiveness, we considered whether augmentation of bronchial responsiveness after inhalation of acetaldehyde is associated with release of endogenous histamine. However, terfenadine failed to prevent the acetaldehyde induced bronchial hyperresponsiveness (fig 1). In the present study terfenadine was administered at sufficient doses to inhibit acetaldehyde induced bronchoconstriction which is caused via histamine release. ${ }^{12}$ In addition, terfenadine is a potent and selective histamine $\mathrm{H}_{1}$ receptor antagonist and does not possess anticholinergic, antiserotonic, or antiadrenergic properties. ${ }^{3132}$ It indicates that histamine and $\mathrm{H}_{1}$ receptor mediated secondary reactions are not responsible for acetaldehyde induced bronchial hyperresponsiveness.

We have recently shown a significant correlation between the bronchial responsiveness to acetaldehyde and the bronchial responsiveness to methacholine, ${ }^{12}$ which was reconfirmed in the present study (fig 2), and that $\mathrm{FEV}_{1}$ was not altered by acetaldehyde inhalation in healthy subjects. In the present study the degree of increased bronchial hyperresponsiveness induced by acetaldehyde was related to the baseline bronchial hyperresponsiveness (fig 3). It suggests that bronchial hyperresponsiveness is a necessary precondition for the expression of bronchial hyperresponsiveness induced by acetaldehyde.

Four asthmatic subjects in our group had no history of alcohol induced asthma, and inhalation of acetaldehyde tended to increase bronchial responsiveness $(p<0 \cdot 1)$. This effect may be non-specific, and may result in an elevation of serum acetaldehyde concentration due to the inability of ALDH 2 to play an important part in ethanol induced asthma. However, the small number of subjects in this study make it difficult to reach a firm conclusion.

In conclusion, the subthreshold concentration of acetaldehyde increases non-specific bronchial responsiveness in asthmatic subjects, and the acetaldehyde induced bronchial hyperresponsiveness observed in asthmatics may, in the future, help to guide more physiological studies that could define the mechanism of alcohol induced bronchial hyperresponsiveness.

1 Watanabe T. Mechanism of ethanol-induced bronchoconstriction in Japanese asthmatic patients. $\mathcal{F} p n \mathcal{F}$ Allergol 1991;40:1210-7.

2 Sakurai S, Kobayashi Y, Okada T, Ohya N. A clinical investigation of acute exacerbation after drinking of alcoholic beverage. Kokyu 1992:11:1340-7 (English abstract)

3 Ayres JG, Ancic P, Clark TJH. Airway responses to oral ethanol in normal subjects and in patients with asthma. ethanol in normal subjects and in

4 Ayres JG, Clark TJH. Alcoholic drinks and asthma: a survey. Br $\mathcal{F}$ Dis Chest 1983;77:370-5.

5 Zellweger JP. Asthme et rhinite déclenchés par l'ingestion d'éthanol pur et par l'inhalation de vapeurs d'alcool. Schweiz Med Wschr 1982;112:212-4.

6 Greenfild NJ, Pietruszko R. Two aldehyde dehydrogenase from human liver. Isolation via affinity chromatography and characterization of the isozymes. Biochem Biophys Acta 1977;483:35-45.

7 Harada S, Agarwal DP, Goedde HW. Electrophoretic and biochemical studies of human aldehyde dehydrogenase
isozymes in various tissues. Life Science 1980;26:1773-80. isozymes in various tissues. Life Science 1980;26:1773-80.
8 Koivula T. Subcellular distribution and characterization of human liver aldehyde dehydrogenase fractions. Life Science 1975;16:1563-70.

9 Agarwal DP, Harada S, Goedde HW. Racial differences in biological sensitivity to ethanol. The role of alcoho dehydrogenase isozymes. Alc Clin Exp Res 1981;5:12-6.

10 Goedde HW. Liver alcohol dehydrogenase and aldehyde dehydrogenase in the Japanese: isozyme variation and its possible role in alcohol intoxication. Am $\mathcal{f}$ Hum Genet 1980;32:8-15.

11 Harada S, Agarwal DP, Goedde HW. Isozymes of alcohol dehydrogenase and their role in alcohol sensitivity. $A d v$ Exp Med Biol 1980;132:31-9.

12 Myou S, Fujimura M, Nishi K, Ohka T, Matsuda T. Aerosolized acetaldehyde induces histamine-mediated bronchoconstriction in asthmatics. Am Rev Respir Dis bronchoconstric

13 Cockcroft DW, Killian DM, Mellon JJA, Hargreave FE Bronchial reactivity to inhaled histamine: a method and Bronchial reactivity to inhaled histamine: a
clinical survey. Clin Allergy 1977;7:235-43.

14 Yak K, Salone C, Woolcock AJ. Rapid method for measurement of bronchial responsiveness. Thorax 1983;38:760-5.

15 Juniper EF, Frith PA, Hargreave FE. Airway responsiveness to histamine and methacholine: relationship to minimum treatment to control symptoms of asthma. Thorax $1981 ; 36: 575-9$

16 Ryan G, Latimer KM, Dolovich J, Hargreave FE. Bron- 
chial responsiveness to histamine: relationship to diurnal variation of peak flow rate, improvement after bronchodilator, and airway calibre. Thorax 1982;37:423-9.

17 American Thoracic Society. Standard for diagnosis and care of patients with chronic obstructive pulmonary disease (COPD) and asthma. Am Rev Respir Dis 1987;136:225-44.

18 Akabane J, Nakanishi S, Kohei H, Asakawa S, Matsumura $\mathrm{R}$, Ogata $\mathrm{H}$, et al. Studies on sympathomimetic action of acetaldehyde. I. Experiments with blood pressure and nictitating membrane responses. $f_{p n}$ f Pharmacol nictitating memb
$1964 ; 14: 295-307$.

19 Herman H, Chatonnet J, Vial J. Les propriétés pharmacodynamiques et particuliérement sympathicomimétiques de l'éthanol. Arch Int Phamacodyn Ther 1955;102:432-49.

20 Perman ES. The effect of acetaldehyde on the secretion of adrenaline and noradrenaline from the suprarenal gland of the cat. Acta Physiol Scand 1958;43:71-6.

21 Warren JB, Dalton N. A comparison of the bronchodilator and vasopressor effects of exercise levels of adrenaline in man. Clin Sci 1983;64:475-9.

22 Barnes PJ, Fitzgerald GA, Dollery CT. Circadian variation in adrenergic responses in asthmatic subjects. Clin $\mathrm{Sci}$ Mol Med 1982;62:349-54.

23 Murlas C, Nadel JA, Roberts JM. The muscarinic receptors of airway smooth muscle: their characterization in vitro. f Appl Physiol 1982;52:1084-91.

24 Patel KR. Effect of terfenadine on methacholine-induced bronchoconstriction in asthma. $\mathcal{F}$ Allergy Clin Immunol 1987;79:355-8.
25 Rafferty P, Holgate ST. Terfenadine (Seldane) is a potent and selective histamine $H_{1}$ receptor antagonist in asthmatic airways. Am Rev Respir Dis 1987;135:181-4.

26 Anderson WH, Krzanowski JJ, Polson JB, Szentivanyi A Increased synthesis of prostaglandin-like material during histamine tachyphylaxis in canine tracheal smooth muscle. Biochem Pharmacol 1979;28:2223-6.

27 Yen SS, Mathe AA, Dugan JJ. Release of prostaglandins from healthy and sensitized guinea pig lung and trachea by histamine. Prostaglandins 1976;11:227-39.

28 Berti F, Folco GC, Nicosia S, Omini C, Pasargiklian R. The role of histamine $\mathrm{H}_{1}$ - and $\mathrm{H}_{2}$-receptors in the generation of thromboxane $A_{1}$ in perfused guinea pig lungs. $B r f$ of thromboxane $A_{1}$ in perf

29 Rossoni G, Omini C, Vigano T, Mandelli V, Folco GC, Berti F. Bronchoconstriction by histamine and bradykinin in guinea pigs: relationship to thromboxane A generation and effect of aspirin. Prostaglandins 1980;20:547-57.

30 Dorsch W, Hintschich C, Neuhauser J, Weber J. Sequential histamine inhalations cause increased bronchial histamine reactivity in guinea pigs: role of platelets, thromboxanes and prostacyclin. Naunyn Schmiedeberg Arch Pharmacol 1984;327:148-55.

31 Cheng HC, Woodward JK. A kinetic study of the antihistamine effect of terfenadine. Arzneimittelforschung 1982;32:1160-6.

32 Nicholson AN. Antihistaminic activity and central effects of terfenadine. A review of European studies. Arzneimittelforschung 1982;32:1191-3. 